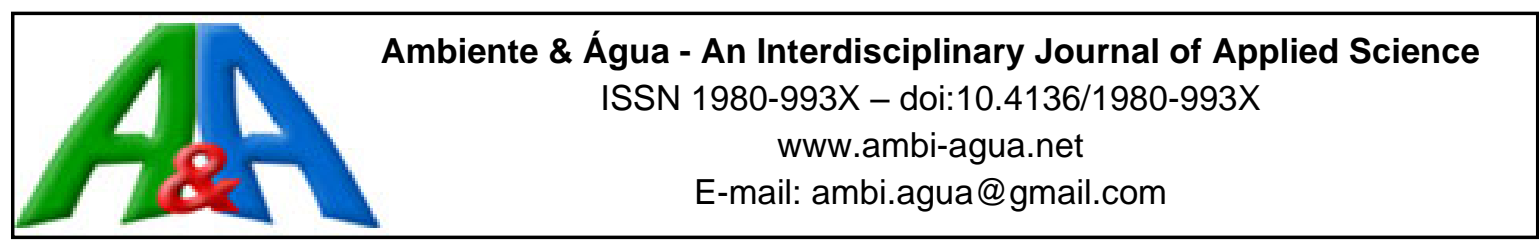

\title{
Heavy metals in soils and forage grasses irrigated with Vieira River water, Montes Claros, Brazil, contaminated with sewage wastewater
}

\author{
ARTICLES doi:10.4136/ambi-agua.2440
}

Received: 11 Jul. 2019; Accepted: 06 Feb. 2020

\begin{abstract}
Matheus Mendes Reis ${ }^{1 *}$; Leonardo David Tuffi Santos ${ }^{2}$; Ariovaldo José da Silva1 ${ }^{1}$; Gevany Paulino de Pinho ${ }^{2}$; Leonardo Michel Rocha ${ }^{2}$ JD

${ }^{1}$ Faculdade de Engenharia Agrícola. Universidade Estadual de Campinas (UNICAMP), Avenida Cândido Rondon, n 501, CEP: 13083-875, Campinas, SP, Brazil. E-mail: arijs@unicamp.br

${ }^{2}$ Instituto de Ciências Agrárias. Universidade Federal de Minas Gerais (UFMG), Avenida Universitária, n¹000, CEP: 39404-547, Montes Claros, MG, Brazil. E-mail: ltuffi@yahoo.com.br, gevanypp@yahoo.com.br, leonardorocha.agronomia@gmail.com

*Corresponding author. E-mail: matheussmendes@hotmail.com
\end{abstract}

\begin{abstract}
There is great concern with soil and plant contamination by heavy metals due to the use of polluted water in agricultural irrigation. In this study, areas irrigated with Vieira River water were evaluated as to contamination by $\mathrm{As}, \mathrm{Cr}, \mathrm{Cu}, \mathrm{Ni}, \mathrm{Pb}$ and $\mathrm{Zn}$. The Vieira River receives effluent from Montes Claros city, state of Minas Gerais, Brazil. To do so, two irrigated areas were selected, one upstream and one downstream of the Montes Claros city. Wastewater discharge increased the concentration of $\mathrm{As}$ and $\mathrm{Ni}$ in the water of Vieira River, and consequently, of $\mathrm{As}, \mathrm{Cr}, \mathrm{Cu}, \mathrm{Ni}, \mathrm{Pb}$ and $\mathrm{Zn}$ in the soil and of $\mathrm{As}$ and $\mathrm{Zn}$ in forage grasses. However, the content of heavy metals in the soil did not exceed the internationally recommended limits. Pollution load index (PLI) and contamination factor (CF) indicated the existence of pollution and moderate contamination in downstream soils of the city of Montes Claros. Potential ecological risk index $(\mathrm{RI})$ and ecological risk factor $\left(\mathrm{E}_{\mathrm{r}}\right)$ indicated a low ecological risk, but these indicators were higher in downstream soils of Montes Claros. Arsenic (As) was the only heavy metal that featured a transfer factor (TF) higher than the widespread values found in literature and positive geoaccumulation index $\left(\mathrm{I}_{\mathrm{geo}}\right)$, indicative of anthropogenic pollution.
\end{abstract}

Keywords: ecological risk, geoaccumulation index, water contaminated.

\section{Metais pesados em solos e plantas forrageiras irrigadas com água do Rio Vieira, Montes Claros, Brasil, contaminada com efluentes de esgoto}

\section{RESUMO}

A contaminação de solo e plantas por metais pesados devido ao uso de águas poluídas na irrigação agrícola é motivo de grande preocupação. No presente estudo, áreas irrigadas com água do rio Vieira foram avaliadas quanto a contaminação por $\mathrm{As}, \mathrm{Cr}, \mathrm{Cu}, \mathrm{Ni}, \mathrm{Pb}$ e $\mathrm{Zn}$. Para isso foram selecionadas duas áreas, uma a montante e outra a jusante da cidade de Montes Claros. A descarga de água residuária aumentou a concentração de As e Ni na água do rio 
Vieira; e, consequentemente, de $\mathrm{As}, \mathrm{Cr}, \mathrm{Cu}, \mathrm{Ni}, \mathrm{Pb}$ e $\mathrm{Zn}$ no solo; e de $\mathrm{As}$ e $\mathrm{Zn}$ em plantas forrageiras. No entanto, os teores de metais pesados no solo não excederam os limites internacionais recomendados. O índice de carga de poluição (PLI) e o fator de contaminação (CF) indicaram existência de poluição e contaminação moderada em solos a jusante da cidade de Montes Claros. O índice de risco ecológico potencial (RI) e o coeficiente de risco ecológico $\left(\mathrm{E}_{\mathrm{r}}\right)$ indicaram baixo risco ecológico, porém esses indicadores foram maiores no solo a jusante de Montes Claros. O As foi o único metal pesado que apresentou fator de transferência (TF) maior que os valores generalizados encontrados na literatura e índice de geoacumulação (Igeo) positivo, indicativo de poluição antropogênica.

Palavras-chave: água contaminada, índice de geoacumulação, risco ecológico.

\section{INTRODUCTION}

The dispersal of heavy metals in irrigated agricultural areas is growing, which results in food contamination that can be harmful for animals and humans. Heavy metals have low solubility, and are not degradable in water, which contributes to their accumulation in soil, and therefore in plants cultivated on these irrigated areas with contaminated water. Heavy metals' transfer from soils to plants is one of the main ways of humans exposure through the food chain (Chopra and Pathak, 2015).

Until 2010, Vieira River was the main river receiving untreated sewage produced in the city of Montes Claros, state of Minas Gerais, Brazil. Currently, the river still receives city sewage; however, there is a prior treatment process, carried out in the wastewater treatment plant (WWTP) of Montes Claros. In the margins of Vieira River, there are farms that use its water for the irrigation of pastures; nevertheless, there are no studies on heavy metal contamination of soil and plants irrigated with the river water.

The intake of heavy metals through the food chain has been widely disseminated throughout the world (Chary et al., 2008; Chopra and Pathak, 2015). Heavy metals are nonbiodegradable and persistent compounds, which, because of these characteristics, accumulate in vital organs of the human body, such as kidneys, bones and liver, and are associated with several serious health disorders, such as diarrhea, stomatitis, tremor, ataxia, paralysis, convulsion, depression, and pneumonia (McCluggage, 1991). The nature of the effects of these disorders can be toxic, neurotoxic, carcinogenic, mutagenic, or teratogenic (EU, 2002).

This study assessed the concentration of $\mathrm{As}, \mathrm{Cr}, \mathrm{Cu}, \mathrm{Ni}, \mathrm{Pb}$, and $\mathrm{Zn}$ in water, soil, and forage grasses in areas irrigated with Vieira River water.

\section{MATERIALS AND METHODS}

\subsection{Study area}

The study area is located in the city of Montes Claros, Brazil, in the North of the state of Minas Gerais. The climate of the region is classified, according to Köppen, as Aw. Vieira River is the main receiver of wastewater of domestic and industrial sewage of Montes Claros. Vieira River rises in the south of Montes Claros and flows through residential and industrial areas before joining Verde Grande River, one of the main affluents of the middle region of the São Francisco River Basin. The length of the main course of Vieira River and the area of its basin is approximately $42 \mathrm{~km}$ and $580 \mathrm{~km}^{2}$, respectively. The Wastewater Treatment Plant (WWTP) is located in Northern Montes Claros (Figure 1). Several industry plants are located west of the WWTP (Figure 1), including textile, biofuels, food, pharmaceutical, and mining industries. About $1 \mathrm{~km}$ east of the WWTP, there is another textile factory (Figure 1). 


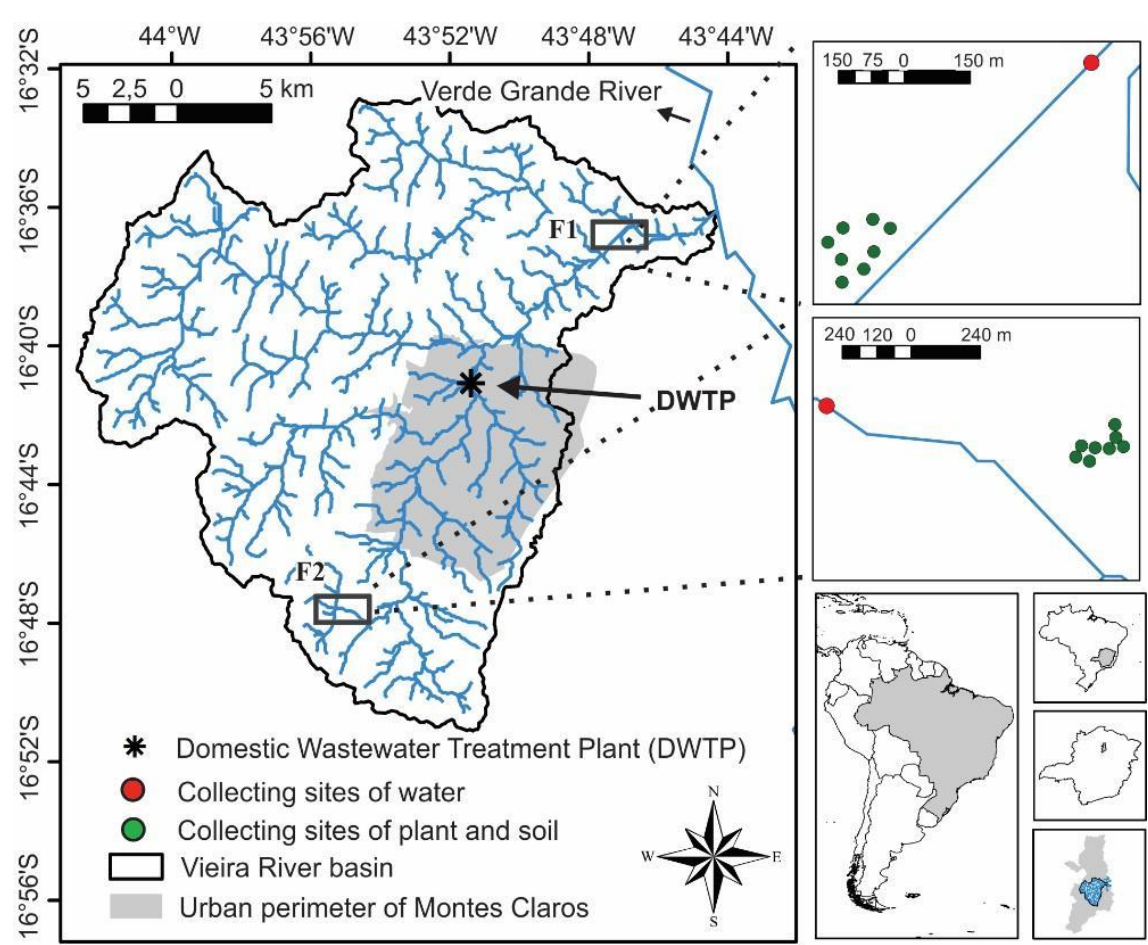

Figure 1. Location map of the study area.

The unpleasant odor and presence of solid residues and white foam in waters of Vieira River are easily observed in stretches passing through Montes Claros and downstream of WWTP.

\subsection{Sample collection}

To evaluate levels of contamination by heavy metals in areas irrigated with Vieira River water, samples of water, soil, and plants were collected at two farms (sites F1 and F2 in Figure 1) in July 2015. The F1 farm is located upstream of the city of Montes Claros and uses Vieira River water for irrigation of forage grasses (Pennisetum purpureum), and the irrigation system used is the sprinkler. The F2 farm is located downstream of the city of Montes Claros and diverts part of the Vieira River water to an area of flood irrigation, which cultivates forage grasses (Brachiaria mutica) for feeding the cattle of milk producers.

Samples of unfiltered water of the river were collected approximately $10 \mathrm{~m}$ from the margin, where the water used in irrigation is collected. The water samples were stored in polypropylene bottles that had been previously washed with $\mathrm{HNO}_{3}(10 \%)$. To preserve the water samples, about $1.5 \mathrm{~mL}$ of $\mathrm{HNO}_{3}(65 \%)$ was added to reduce their $\mathrm{pH}$ to values lower than 2. Sampling bottles were kept in coolers with ice during their transportation to the laboratory, where they were stored in a refrigerator at temperatures between 0 and $4{ }^{\circ} \mathrm{C}$ until the quantification of heavy metals (APHA et al., 1998).

At each farm (F1 and F2), eight sites were selected for the collection of samples of soil and forage grasses (Figure 1). Each sample was composed of three subsamples collected in an area of $1 \mathrm{~m}^{2}$. Samples were placed in plastic bags and sealed for transportation and storage (Gebrekidan et al., 2013).

Soil samples were collected in the 0-20 cm layer. In the laboratory, samples were dried in an oven at $60^{\circ} \mathrm{C}$ for 72 hours, homogenized in an agate mortar and pistil, and sieved in a Nylon sieve of $0.3 \mathrm{~mm}$.

In the samplings of plant material, the plants were cut to $4 \mathrm{~cm}$ from the ground. In the laboratory, samples were washed with tap water and distilled water for removing particulate material deposited on the surface of the plant. Then, all samples were dried in an oven at $75^{\circ} \mathrm{C}$

\section{IPABH}

Rev. Ambient. Água vol. 15 n. 2, e2440 - Taubaté 2020 
until constant weight, grinded, and sieved (Nylon sieve of $0.3 \mathrm{~mm}$ ).

The sieved soil and plant samples were stored in Falcon tubes for further analysis of heavy metal content.

\subsection{Chemical analysis}

The stock standard solution of $1000 \mathrm{mg} \mathrm{L}^{-1}$ for atomic absorption spectroscopy of Sigma Aldrich (Germany), diluted in different concentrations with ultrapure water (Milli-Q, Millipore), was used for the preparation of analytical curves. $\mathrm{Cr}, \mathrm{Cu}, \mathrm{Ni}, \mathrm{Pb}$, and $\mathrm{Zn}$ elements were measured in flame atomization mode, composed of Ar-acetylene (acetylene 2.8 AA), and the As element was determined by a hydride generator system using argon (99.999\% purity) and Ar-acetylene (acetylene 2.8 AA) (APHA et al., 1998). All analyses were performed in triplicate.

For total metal analysis, $100 \mathrm{~mL}$ of the water sample was mixed with $10 \mathrm{~mL}$ of $\mathrm{HNO}_{3}$ $(65 \%, \mathrm{PA})$ and taken to a hot plate, in which it was evaporated to a volume from 10 to $20 \mathrm{~mL}$ (APHA et al., 1998). Digested samples were then filtered through a quantitative filter paper (Unifil, C42, blue stripe) and transferred to Falcon tubes. The volume of each sample was adjusted to $25 \mathrm{~mL}$ using ultrapure water (Milli-Q, Millipore). Concentrations of $\mathrm{As}, \mathrm{Cr}, \mathrm{Cu}, \mathrm{Ni}$, $\mathrm{Pb}$, and $\mathrm{Zn}$ were determined in an atomic absorption spectrophotometer (Varian, AA 240 FS model).

For soil digestion, $0.50 \mathrm{~g}$ of each sample was mixed to $9 \mathrm{~mL}$ of $\mathrm{HNO}_{3}(65 \%$, PA) and 3 $\mathrm{mL}$ of $\mathrm{HCl}(37 \%)$ and microwave digested (Mars 6, CEM) according to the USEPA 3051A method (USEPA, 1998). In the case of forage grasses, $0.01 \mathrm{~g}$ of each sample was mixed with $10 \mathrm{~mL}$ of $\mathrm{HNO}_{3}(65 \%, \mathrm{PA})$ and digested in a similar way to the soil samples.

After the digestion process, soil and plant samples were then filtered through a quantitative filter paper (Unifil, C42, blue stripe) and diluted with ultrapure water (Milli-Q, Millipore) until it reached a volume of $25 \mathrm{~mL}$. Concentrations of $\mathrm{As}, \mathrm{Cr}, \mathrm{Cu}, \mathrm{Ni}, \mathrm{Pb}$, and $\mathrm{Zn}$ were determined in an atomic absorption spectrophotometer (Varian, AA 240 FS model).

\subsection{Indicators and Statistical analysis}

To understand the impact of heavy metals present in the soil, the following were calculated: contamination factor (CF) (Equation 1); pollution load index (PLI) (Equation 2); geoaccumulation index ( $\mathrm{I}_{\mathrm{geo}}$ ) (Equation 3); and potential ecological risk index (RI) (Equation 4). Assessment of contamination level by heavy metals using these factors has been successfully employed in several studies (Varol, 2011; Wang et al., 2018).

$$
C F=\frac{C_{\text {heavy metal }}}{C_{\text {background }}}
$$

$\mathrm{CF}$ is the ratio between each metal content in soil samples and the background value. The adopted background values were $0.23 \mathrm{mg} \mathrm{kg}^{-1}$ for As (Kabata-Pendias and Pendias, 1999); 35.00; 25.00; 20.00; and $20.00 \mathrm{mg} \mathrm{kg}^{-1}$ for $\mathrm{Cr}, \mathrm{Cu}, \mathrm{Ni}$, and $\mathrm{Pb}$, respectively (Taylor and McLennan, 1995); and $49.50 \mathrm{mg} \mathrm{kg}^{-1}$ for Zn (Turekian and Wedepohl, 1961).

Interpretation of CF values was suggested by Hakanson (1980), according to which CF < 1 indicates low contamination; $1<\mathrm{CF}<3$ indicates moderate contamination; $3<\mathrm{CF}<6$ indicates considerable contamination; $\mathrm{CF}>6$ indicates very high contamination.

$$
P L I=\left(C F_{1} \times C F_{2} \times C F_{3} \times \ldots \times C F_{n}\right)^{\frac{1}{n}}
$$

Where CF is the contamination factor, and $n$ is the number of metal species. PLI presents a general overview of pollution in each sampling site and also shows the contribution of each 
metal to pollution. PLI $<1$ indicates that there is no pollution by heavy metals in the site; however, PLI > 1 indicates that there is pollution (Varol, 2011).

$\mathrm{I}_{\text {geo }}$ determines metal contamination in soils, comparing current contents with background values (Equation 3).

$$
I_{g e o}=\left[\frac{C_{n}}{1.5 B_{n}}\right]
$$

Where $\mathrm{C}_{\mathrm{n}}$ is the $n$ metal concentration in soil samples, and $\mathrm{B}_{\mathrm{n}}$ is the background value of the $n$ element. The factor 1.5 is introduced in the equation to minimize possible variation in the background value, which can be attributed to lithospheric effects. The seven categories of the geoaccumulation index are presented as follows: $\mathrm{I}_{\text {geo }}<0$, practically uncontaminated; $0 \leq \mathrm{I}_{\text {geo }}<1$, uncontaminated to moderately polluted; $1 \leq \mathrm{I}_{\text {geo }}<2$, moderately polluted; $2 \leq$ Igeo $_{\text {ge }}<3$, moderately to heavily polluted; $3 \leq$ Igeo $_{\text {ge }}<4$, heavily polluted; $4 \leq$ Igeo $_{\text {ge }}<5$, heavily to extremely polluted; and $\mathrm{I}_{\mathrm{geo}}>5$, extremely polluted.

$\mathrm{RI}$ is a factor used to evaluate the potential ecological risk of heavy metals in soils and was initially proposed by Hakanson (1980) (Equation 4).

$$
\mathrm{RI}=\sum_{\mathrm{i}=1}^{\mathrm{n}} \mathrm{E}_{\mathrm{r}}=\sum_{\mathrm{i}=1}^{\mathrm{n}} \mathrm{T}_{\mathrm{r}} \times \mathrm{CF}
$$

Where $\mathrm{E}_{\mathrm{r}}$ is the ecological risk factor of a certain heavy metal and $\mathrm{T}_{\mathrm{r}}$ is the toxicity factor of a single metal. Toxicity factors of $\mathrm{As}, \mathrm{Cr}, \mathrm{Cu}, \mathrm{Ni}, \mathrm{Pb}$, and $\mathrm{Zn}$ were 10, 2, 5, 5, 5, and 1, respectively (Hakanson, 1980). Criteria for the $E_{\mathrm{r}}$ classification are: $\mathrm{E}_{\mathrm{r}}<40$, low potential ecological risk; $40 \leq \mathrm{E}_{\mathrm{r}}<80$, moderate potential ecological risk; $80 \leq \mathrm{E}_{\mathrm{r}}<160$, considerable potential ecological risk; $160 \leq \mathrm{E}_{\mathrm{r}}<320$, high potential ecological risk; and $\mathrm{E}_{\mathrm{r}} \geq 320$, very high potential ecological risk (Hakanson, 1980). The RI classification introduced by Hakanson (1980) was based on eight parameters (As, Cd, Cr, Cu, Hg, Pb, Zn, and PCBs). In this study, all these parameters were not evaluated, therefore, the RI classification should be adjusted according to the number of parameters and the ratio of toxicity coefficient of each parameter (Wang et al., 2018). The adjusted RI classification is: $\mathrm{RI}<110$, low ecological risk; $110 \leq \mathrm{RI}<220$, moderate ecological risk; $220 \leq \mathrm{RI}<440$, considerable ecological risk; and $\mathrm{RI} \geq 440$, very high ecological risk.

For understanding the bioavailability of a heavy metal, was calculated the transfer factor (TF), which in this study was determined by the relationship between the metal content in the shoot of the plants and in the soil (Equation 5) (Gebrekidan et al., 2013).

$$
T F=\frac{\text { Metal content in the shoot of the plant }}{\text { Metal content in the soil }}
$$

Analysis of variance (ANOVA) and F-test were conducted at 5\% error probability level to verify differences in contamination by heavy metals between upstream (F1) and downstream (F2) of the city of Montes Claros. All statistical analyses were carried out using the R-plus ${ }^{\circledR}$ 3.4.2. software (R Development Core Team, 2017).

\section{RESULTS AND DISCUSSION}

\subsection{Heavy metal contamination in water of Vieira River used in irrigation}

The concentrations of heavy metals As and Ni were significantly higher $(\mathrm{p}<0.01)$ in the water of Vieira River at the farm margins downstream of the city of Montes Claros (F2), when compared with the water of the river at the farm margins upstream $(\mathrm{F} 1)$. On the other hand, $\mathrm{Cu}$ featured the higher concentration $(p<0.01)$ in the water of Vieira River at the F1 margins. None of the concentration values of heavy metals found in the two farms (F1 and F2) were higher than the international limits recommended for water use in irrigation (USEPA, 2012;

\section{IPABH}


WHO, 2006). However, $\mathrm{Cu}$ and $\mathrm{Ni}$ exceeded the limits recommended by the Brazilian legislation for the use of water in irrigation (CONAMA, 2009), being $\mathrm{Cu}$ in the two farms (F1 and F2) and $\mathrm{Ni}$ only in F2 (Table 1). It is important to emphasize that the water can be inappropriate for irrigation and superficial flooding depending on the use and occupation of the soil, once this irrigation method can favor the direct contact of animals and humans with the contaminated water.

Table 1. Concentration of heavy metals $\left(\mu \mathrm{g} \mathrm{L}^{-1}\right)$ in water samples of Vieira River for irrigation of F1 and F2 farms, and maximum permitted concentration $\left(\mu \mathrm{g} \mathrm{L}^{-1}\right)$ in water $(\mathrm{n}=3)$.

\begin{tabular}{lccccccc}
\hline \multirow{2}{*}{ Metals } & \multicolumn{2}{c}{ F1 Farm } & \multicolumn{2}{c}{ F2 Farm } & & & \\
\cline { 2 - 5 } & Mean & SD & Mean & SD & & & \\
\hline As $\left(\mu \mathrm{g} \mathrm{L}^{-1}\right)$ & $0.4^{* * *}$ & 0.09 & 1.7 & 0.01 & 33 & 100 & 100 \\
$\mathrm{Cr}\left(\mu \mathrm{g} \mathrm{L}^{-1}\right)$ & 0.0 & 0.00 & 0.0 & 0.00 & 50 & 100 & 100 \\
$\mathrm{Cu}\left(\mu \mathrm{g} \mathrm{L}^{-1}\right)$ & $82.6^{* *}$ & 0.74 & 19.4 & 2.61 & 13 & 200 & 200 \\
$\mathrm{Ni}\left(\mu \mathrm{g} \mathrm{L}^{-1}\right)$ & $0.0^{* *}$ & 0.00 & 52.3 & 1.51 & 25 & 200 & 200 \\
$\mathrm{~Pb}\left(\mu \mathrm{g} \mathrm{L}^{-1}\right)$ & 0.0 & 0.00 & 0.0 & 0.00 & 33 & 5000 & 5000 \\
$\mathrm{Zn}\left(\mu \mathrm{g} \mathrm{L}^{-1}\right)$ & 189.1 & 5.94 & 197.6 & 23.25 & 5000 & 2000 & 2000 \\
\hline
\end{tabular}

$\mathrm{SD}$ - Standard deviation; and $* *(\mathrm{p}<0.01)$ indicates statistical difference (ANOVA; F-test) between mean values of metals in $\mathrm{F} 1$ and $\mathrm{F} 2$.

\subsection{Heavy metal contamination in soil irrigated with water of Vieira River}

Contents of $\mathrm{As}, \mathrm{Cr}, \mathrm{Cu}, \mathrm{Ni}, \mathrm{Pb}$, and $\mathrm{Zn}$ in samples of soil irrigated with water of Vieira River in F2 were significantly higher $(p<0.05)$ than in F1 (Table 2), which indicates anthropogenic pollution of Vieira River waters, possibly due to the discharge of domestic and industrial wastewater generated in Montes Claros. The highest concentration of As and $\mathrm{Ni}$ in water samples collected at F2 (Table 1) also reinforces the indications of anthropogenic pollution of Vieira River waters.

Table 2. Content of heavy metals ( $\left.\mathrm{mg} \mathrm{kg}^{-1}\right)$, contamination factor (CF), and pollution load index (PLI) in soil irrigated with Vieira River water in two farms (F1 and F2) $(\mathrm{n}=8)$.

\begin{tabular}{|c|c|c|c|c|c|c|c|c|}
\hline \multirow{2}{*}{ Metals } & \multicolumn{3}{|c|}{ F1 Farm } & \multicolumn{3}{|c|}{ F2 Farm } & \multicolumn{2}{|c|}{ Maximum allowed } \\
\hline & Mean & $\mathrm{SD}$ & $\mathrm{CF}$ & Mean & $\mathrm{SD}$ & $\mathrm{CF}$ & Ewers (1991) & CONAMA (2009) \\
\hline As $\left(\mathrm{mg} \mathrm{kg}^{-1}\right)$ & 0.3 & 0.05 & 1.40 & $0.6^{* *}$ & 0.12 & 2.50 & 20.0 & 35.0 \\
\hline $\mathrm{Cr}\left(\mathrm{mg} \mathrm{kg}^{-1}\right)$ & 30.5 & 5.33 & 0.87 & $42.5 * *$ & 5.27 & 1.21 & 100.0 & 150.0 \\
\hline $\mathrm{Cu}\left(\mathrm{mg} \mathrm{kg}^{-1}\right)$ & 15.9 & 4.01 & 0.64 & $20.0 *$ & 1.73 & 0.80 & 100.0 & 200.0 \\
\hline $\mathrm{Ni}\left(\mathrm{mg} \mathrm{kg}^{-1}\right)$ & 5.5 & 1.53 & 0.28 & $15.9 * *$ & 0.86 & 0.79 & 50.0 & 70.0 \\
\hline $\mathrm{Pb}\left(\mathrm{mg} \mathrm{kg}^{-1}\right)$ & 10.2 & 2.50 & 0.51 & $13.7 * *$ & 2.10 & 0.69 & 100.0 & 180.0 \\
\hline $\mathrm{Zn}\left(\mathrm{mg} \mathrm{kg}^{-1}\right)$ & 33.9 & 6.73 & 0.69 & $53.3 * *$ & 7.97 & 1.08 & 300.0 & 450.0 \\
\hline PLI & & & 0.65 & & & 1.06 & & \\
\hline
\end{tabular}

SD - Standard Deviation; CF - contamination factor; PLI - pollution load index; * $(\mathrm{p}<0.05)$ and $* *(\mathrm{p}$ $<0.01$ ) indicate statistical difference (ANOVA; F-test) between mean values of metals in F1 and F2.

Contents of heavy metals in the soil of the study area were higher at F2 farm, downstream of the city of Montes Claros, when compared with those reported by Gebrekidan et al. (2013) for $\mathrm{Cr}\left(31.02 \mathrm{mg} \mathrm{kg}^{-1}\right), \mathrm{Pb}\left(3.27 \mathrm{mg} \mathrm{kg}^{-1}\right)$, and $\mathrm{Zn}\left(51.83 \mathrm{mg} \mathrm{kg}^{-1}\right)$, except $\mathrm{Cu}\left(25.25 \mathrm{mg} \mathrm{kg}^{-1}\right)$ and $\mathrm{Ni}\left(26.00 \mathrm{mg} \mathrm{kg}^{-1}\right)$ in areas irrigated with water of the Ginfel River, polluted by wastewater produced in Sheba Tannery, Ethiopia. The Cr content reported by Chary et al. (2008) (33.00 \pm $\left.12.00 \mathrm{mg} \mathrm{kg}^{-1}\right)$ and by Singh et al. (2010) (19.21 $\left.\pm 3.26 \mathrm{mg} \mathrm{kg}^{-1}\right)$ was also lower than the mean value found in F2. However, no heavy metal detected in both farms (F1 and F2) featured values 
higher than international and Brazilian limits recommended for soils (CONAMA, 2009; Ewers, 1991) (Table 2).

$\mathrm{CF}$ values indicated that $\mathrm{Cu}, \mathrm{Ni}$, and $\mathrm{Pb}$ in both farms (F1 and $\mathrm{F} 2$ ) and $\mathrm{Cr}$ and $\mathrm{Zn}$ in $\mathrm{F} 1$ farm presented low level of contamination. $\mathrm{Cr}$ and $\mathrm{Zn}$ in F2 and As in both farms (F1 and F2) showed a moderate level of contamination, according to CF (Hakanson, 1980). PLI indicates the existence of heavy-metal pollution in soil irrigated with the water of Vieira River downstream of Montes Claros, despite the its value in F2 being very close to the limit (PLI = 1) that indicates whether or not there is pollution (Varol, 2011) (Table 2).

Mean values of geoaccumulation index ( $\left.\mathrm{I}_{\text {geo }}\right)$ in the soils of both farms (F1 and F2) accounted for the following descending order: $\mathrm{As}>\mathrm{Cr}>\mathrm{Zn}>\mathrm{Cu}>\mathrm{Pb}>\mathrm{Ni}$. The As in $\mathrm{F} 2$ was the only heavy metal that featured positive Igeo values, indicating the presence of pollution. Igeo value for As in F2 was 0.74, which characterizes the soil in that area as unpolluted to moderately polluted (Table 3). Igeo values for $\mathrm{Cr}, \mathrm{Cu}, \mathrm{Ni}, \mathrm{Pb}$, and $\mathrm{Zn}$ in both farms (F1 and $\mathrm{F} 2$ ) and for $\mathrm{As}$ in F2 were negative, indicating absence of pollution in soils (Table 3).

Table 3. Assessment of geoaccumulation indices $\left(\mathrm{I}_{\mathrm{geo}}\right)$ and potential ecological risk for pollution by heavy metals in samples of soil irrigated with Vieira River water in two farms (F1 and F2) $(n=8)$.

\begin{tabular}{|c|c|c|c|c|c|c|c|c|}
\hline \multirow{2}{*}{ Sites } & \multicolumn{6}{|c|}{$\mathrm{I}_{\text {geo }}$} & \multirow{2}{*}{\multicolumn{2}{|c|}{ Mean }} \\
\hline & As & $\mathrm{Cr}$ & $\mathrm{Cu}$ & $\mathrm{Ni}$ & $\mathrm{Pb}$ & $\mathrm{Zn}$ & & \\
\hline F1 Farm & -0.10 & -0.78 & -1.24 & -2.44 & -1.56 & -1.13 & & \\
\hline F2 Farm & 0.74 & -0.31 & -0.90 & -0.92 & -1.13 & -0.48 & & \\
\hline Mean & 0.32 & -0.54 & -1.07 & -1.68 & -1.34 & -0.80 & & \\
\hline \multirow{2}{*}{ Sites } & \multicolumn{6}{|c|}{$\mathrm{E}_{\mathrm{r}}$} & \multirow{2}{*}{ RI } & \multirow{2}{*}{$\begin{array}{l}\text { Risk } \\
\text { level }\end{array}$} \\
\hline & As & $\mathrm{Cr}$ & $\mathrm{Cu}$ & $\mathrm{Ni}$ & $\mathrm{Pb}$ & $\mathrm{Zn}$ & & \\
\hline F1 Farm & 13.98 & 2.21 & 3.85 & 1.25 & 1.31 & 6.97 & 29.56 & Low \\
\hline F2 Farm & 25.04 & 3.08 & 4.85 & 3.57 & 1.77 & 10.96 & 49.26 & Low \\
\hline Mean & 19.51 & 2.64 & 4.35 & 2.41 & 1.54 & 8.96 & 39.41 & Low \\
\hline
\end{tabular}

$\mathrm{RI}$ - potential ecological risk index; and $\mathrm{E}_{\mathrm{r}}$ - ecological risk factor of certain heavy metal.

Mean $E_{r}$ of each analyzed heavy metal accounted for the following descending order: As $>\mathrm{Zn}>\mathrm{Cu}>\mathrm{Cr}>\mathrm{Ni}>\mathrm{Pb}$. All analyzed metals (As, $\mathrm{Cr}, \mathrm{Cu}, \mathrm{Ni}, \mathrm{Pb}$, and $\mathrm{Zn}$ ) featured low ecological risk in both farms ( $\mathrm{F} 1$ and $\mathrm{F} 2$ ), according to the $\mathrm{E}_{\mathrm{r}}$ classification proposed by Hakanson (1980). Nevertheless, $E_{r}$ values were higher in F2, which indicates increased ecological risk in soils irrigated with water of Vieira River downstream of Montes Claros (Table 3). RI values were much lower than 110 in all sampling sites, indicating a low potential ecological risk. The As significantly contributed to the environmental RI, which can be attributed to the effect of anthropogenic activities. The As is used as preservative for leather and wood, additive for metal alloys, and in herbicides (Halli et al., 2014; Thuong et al., 2013). RI value was also higher at F2 (Table 3).

\subsection{Heavy metal contamination in plants irrigated with water of Vieira River}

Contents of As and $\mathrm{Zn}$ in Brachiaria mutica plants in F2 were significantly higher $(\mathrm{p}<0.05)$ than those found in Pennisetum purpureum plants in F1. On the other hand, Cu featured higher concentration $(\mathrm{p}<0.01)$ in Pennisetum purpureum plants $(\mathrm{F} 1)$. The mean content of heavy metals in plants of both farms (F1 and F2) accounted for the following descending order: $\mathrm{Zn}>\mathrm{Cu}>\mathrm{Ni}>\mathrm{As}$. $\mathrm{Cr}$ and $\mathrm{Pb}$ were not detected in forage grasses in both farms (F1 and F2) (Table 4). 
Table 4. Content of heavy metals $\left(\mathrm{mg} \mathrm{kg}^{-1}\right)$ in forage grasses irrigated with Vieira River water in two farms (F1 and F2) and transfer factor (TF) $(\mathrm{n}=8)$.

\begin{tabular}{cccccccccc}
\hline Metals & \multicolumn{3}{c}{ F1 Farm } & \multicolumn{3}{c}{ F2 Farm } & $\begin{array}{c}\text { Normal } \\
\text { intervals }\end{array}$ & $\begin{array}{c}\text { Agronomic } \\
\text { crop tolerance }^{\mathrm{b}}\end{array}$ & $\begin{array}{c}\text { Widespread } \\
\text { values of TF }^{\mathrm{c}}\end{array}$ \\
\hline $\begin{array}{c}\mathrm{As} \\
\left(\mathrm{mg} \mathrm{kg}^{-1}\right)\end{array}$ & $0.22^{* *}$ & 0.04 & 0.70 & 0.26 & 0.02 & 0.48 & $1-1.7$ & - & $0.01-0.1$ \\
$\begin{array}{c}\mathrm{Cr} \\
\left(\mathrm{mg} \mathrm{kg}^{-1}\right)\end{array}$ & 0.00 & 0.00 & 0.00 & 0.00 & 0.00 & 0.00 & $0.1-0.5$ & 2 & $0.01-0.1$ \\
$\begin{array}{c}\mathrm{Cu} \\
\left(\mathrm{mg} \mathrm{kg}^{-1}\right)\end{array}$ & $7.63^{* *}$ & 0.68 & 0.51 & 4.60 & 1.18 & 0.23 & $5-30$ & $5-20$ & $0.1-1$ \\
$\begin{array}{c}\mathrm{Ni} \\
\left(\mathrm{mg} \mathrm{kg}^{-1}\right)\end{array}$ & 0.50 & 0.35 & 0.10 & 1.05 & 1.11 & 0.07 & $0.1-5$ & $1-10$ & $0.1-1$ \\
$\begin{array}{c}\mathrm{Pb}^{\left(\mathrm{mg} \mathrm{kg}^{-1}\right)} \\
\begin{array}{c}\mathrm{Zn} \\
\left(\mathrm{mg} \mathrm{kg}^{-1}\right)\end{array}\end{array}$ & 0.02 & 0.05 & 0.00 & 0.34 & 0.96 & 0.03 & $5-10$ & $0.5-10$ & $0.01-0.1$ \\
\hline
\end{tabular}

SD - Standard deviation; TF - transfer factor; a - (Kabata-Pendias and Pendias, 2001); b - (KabataPendias and Pendias, 2001; 1999; MacNicol and Beckett, 1985); c - (Kloke et al., 1984).* ( $\mathrm{p}<0.05)$ and $* *(\mathrm{p}<0.01)$ indicate statistical difference (ANOVA; F-test) between mean values of metals in $\mathrm{F} 1$ and $\mathrm{F} 2$.

No metal exceeded the normal intervals (Kabata-Pendias and Pendias, 2001) or the agronomic crop tolerance values (Kabata-Pendias and Pendias, 1999; 2001; MacNicol and Beckett, 1985) (Table 4), including $\mathrm{Cu}$ and $\mathrm{Ni}$, which featured concentrations in the water higher than the limits recommended by the Brazilian legislation for use of water in irrigation (CONAMA, 2005) (Table 1).

The metal content in forage grasses depends not only on the content of metals in the soil, but also on the efficiency of metal transfer from the soil to the plants. This efficiency can be estimated by TF, which is one of the key indicators of human exposure to metals through the food chain (Cao et al., 2014), and is often used to study environmental pollution (Khan et al., 2013). TF values in both farms (F1 and F2) accounted for the following descending order: $\mathrm{Zn}>\mathrm{As}>\mathrm{Cu}$ $>\mathrm{Ni}$. The highest TF values indicated that $\mathrm{Zn}$ and As were easily transferred from the soil to forage grasses when compared with other metals considered in this study. The As was the only metal accounting for TF higher than the widespread values (Kloke et al., 1984) (Table 4).

The As mobility in the soil depends on $\mathrm{pH}$, redox potential, and type and amount of adsorbents (oxides and hydroxides of $\mathrm{Fe}^{3+}, \mathrm{Al}^{3+}, \mathrm{Mn}^{3+}$, or $\mathrm{Mn}^{4+}$, humic substances, and clay minerals) present in the soil (Bissen and Frimmel, 2003; Oscarson et al., 1983). In addition, the amount of As adsorbed in the soil significantly decreased in the presence of organic matter (Bissen and Frimmel, 2003; Redman et al., 2002). Therefore, soil fertilization practices with animal manure at F1 farm, and use for irrigation of Vieira River water contaminated with sewage from Montes Claros at farm F2, contributed to the increase in the organic matter content in soils of these two farms (F1 and F2). This greater amount of organic matter in the soil can result in greater mobility of As (Bissen and Frimmel, 2003; Redman et al., 2002), which corroborates the fact that, in this study, such element featured TF values higher than the widespread values (Table 4).

TF values of heavy metals were lower in F2 when compared with the values in F1 (Table 4), although there is higher content of heavy metal in the F2 soil (Table 2). This can be attributed to frequent flooding and drying of soils in F2 promoted by the flood irrigation system. Xie and Huang (1998) reported that water saturation and drying of soils, promoted by flooded rice irrigation, considerably increased the soil redox potential and, therefore, reduced As solubility and availability. 


\section{CONCLUSION}

Irrigation of agricultural lands with polluted water from Vieira River has increased the concentration of $\mathrm{As}$ and $\mathrm{Ni}$ in water; of $\mathrm{As}, \mathrm{Cr}, \mathrm{Cu}, \mathrm{Ni}, \mathrm{Pb}$, and $\mathrm{Zn}$ in the soil; and of $\mathrm{As}$ and $\mathrm{Zn}$ in forage grasses. Pollution load index (PLI) and contamination factor (CF) indicated the existence of pollution and moderate contamination by $\mathrm{As}, \mathrm{Cr}$, and $\mathrm{Zn}$ in the soil of the farm downstream of the city of Montes Claros (F2), respectively.

Values of the indicators of ecological risk ( $E_{r}$ and $\left.\mathrm{RI}\right)$ observed in the soil of both farms (F1 and F2) showed low ecological risk. However, these indicators were higher in the F2, which indicates increased ecological risk in soils irrigated with water of Vieira River downstream of Montes Claros.

Surface flood irrigation may have contributed to the lower transfer factor (TF) of heavy metals found in the F2 farm; however, the use of this irrigation system in pasture areas is worrisome, because the direct contact of the animal with polluted water from Vieira River may facilitate the contamination of milk or meat of these animals by heavy metals or other inorganic or biological compounds.

Furthermore, there must be greater awareness of contamination of forage grasses and soil by As, since this was the only metal that featured transfer factor (TF) higher than the widespread values found in literature and positive geoaccumulation index $\left(\mathrm{I}_{\mathrm{geo}}\right)$, indicative of anthropogenic pollution.

\section{ACKNOWLEDGMENTS}

The authors thank Fundação de Amparo à Pesquisa do Estado de Minas Gerais (FAPEMIG) and Coordenação de Aperfeiçoamento de Pessoal de Nível Superior (CAPES) for financial support; Conselho Nacional de Desenvolvimento Científico e Tecnológico (CNPq) for providing scholarships and financial support; and Espaço da Escrita - Pró-Reitoria de Pesquisa - UNICAMP - for the language services provided.

\section{REFERENCES}

APHA; AWWA; WEF. Standard Methods for the Examination of Water and Wastewater. 20. ed. Washington, 1998. $1134 \mathrm{p}$.

BISSEN, M.; FRIMMEL, F. H. Arsenic - a Review. Part I: Occurrence, Toxicity, Speciation, Mobility. Acta hydrochimica et hydrobiologica, v. 31, n. 1, p. 9-18, 2003. https://doi.org/10.1002/aheh.200390025

CAO, S.; DUAN, X.; ZHAO, X.; MA, J.; DONG, T.; HUANG, N.; SUN, C.; HE, B.; WEI, F. Health risks from the exposure of children to $\mathrm{As}, \mathrm{Se}, \mathrm{Pb}$ and other heavy metals near the largest coking plant in China. Science of the Total Environment, v. 472, p. 1001-1009, 2014. https://doi.org/10.1016/j.scitotenv.2013.11.124

CHARY, N. S.; KAMALA, C. T.; RAJ, D. S. S. Assessing risk of heavy metals from consuming food grown on sewage irrigated soils and food chain transfer. Ecotoxicology and $\begin{array}{llllllll}\text { Environmental Safety, } & \text { v. 69, n. } & \text { 3, } & \text { p. } & \text { 513-524, }\end{array}$ https://doi.org/10.1016/j.ecoenv.2007.04.013

CHOPRA, A. K.; PATHAK, C. Accumulation of heavy metals in the vegetables grown in wastewater irrigated areas of Dehradun, India with reference to human health risk. Environmental Monitoring and Assessment, v. 187, n. 7, p. 445, 2015. https://doi.org/10.1007/s10661-015-4648-6 
CONAMA. Settlement n. 357 from March 17th 2005. It deals with the classification of water bodies and environmental guidelines for its classification, as well as establishes the conditions and standards for the discharge of effluents, and provides other measures. Diário Oficial [da] União: seção 1, Brasília, DF, n. 053, p. 58-63, 18 mar. 2005.

CONAMA. Settlement n. 420 from December 30th 2009. It provides criteria and guiding values of soil quality for the presence of chemical substances and establishes guidelines for the environmental management of areas contaminated by these substances as a result of anthropic activities. Diário Oficial [da] União: seção 1, Brasília, DF, n. 249, p. 81-84, 30 dez. 2009.

EU. Heavy Metals in Wastes, European Commission on Environment. Denmark, 2002. $86 \mathrm{p}$.

EWERS, U. Standards, guidelines and legislative regulations concerning metals and their compounds. In: MERIAN, E. (Ed.). Metals and their Compounds in the Environment: Occurrence, Analysis and Biological Relevance. Weinheim: VCH, 1991. p. 458-468.

GEBREKIDAN, A.; WELDEGEBRIEL, Y.; HADERA, A.; VAN DER BRUGGEN, B. Toxicological assessment of heavy metals accumulated in vegetables and fruits grown in Ginfel river near Sheba Tannery, Tigray, Northern Ethiopia. Ecotoxicology and $\begin{array}{llllll}\text { Environmental Safety, } & \text { v. } & \text { 95, } & \text { p. } & 171-178,\end{array}$ https://doi.org/10.1016/j.ecoenv.2013.05.035

HAKANSON, L. An ecological risk index for aquatic pollution control. A sedimentological approach. Water Research, v. 14, n. 8, p. 975-1001, 1980. https://doi.org/10.1016/00431354(80)90143-8

HALLI, M.; SARI, E.; KURT, M. A. Assessment of Arsenic and Heavy Metal Pollution in Surface Sediments of the Ergene River, Turkey. Polish Journal of Environmental Studies, v. 23, n. 5, p. 1581-1590, 2014.

KABATA-PENDIAS, A.; PENDIAS, H. Biogeochemistry of Trace Elements. Warsaw: Wyd. Nauk PWN, 1999.

KABATA-PENDIAS, A.; PENDIAS, H. Trace Elements in Soils and Plants. Boca Raton: CRC Press LLC, 2001. 331 p.

KHAN, M. U.; MALIK, R. N.; MUHAMMAD, S. Human health risk from Heavy metal via food crops consumption with wastewater irrigation practices in Pakistan. Chemosphere, v. 93, n. 10, p. 2230-2238, 2013. https://doi.org/10.1016/j.chemosphere.2013.07.067

KLOKE, A.; SAUERBECK, D. R.; VETTER, H. The contamination of plants and soils with heavy metals and the transport of metals in terrestrial food chains. In: NRIAGU, J. O. (Ed.). Changing Metal Cycles and Human Health: Report of the Dahlem Workshop on Changing Metal Cycles and Human Health. Berlin, Germany: Springer, Berlin, 1984. p. 113-141.

MACNICOL, R. D.; BECKETT, P. H. T. Critical tissue concentrations of potentially toxic elements. Plant and Soil, v. 85, n. 1, p. 107-129, 1985. https://doi.org/10.1007/BF02197805

MCCLUGGAGE, D. Heavy Metal Poisoning. Columbus: NCS Magazine. The Bird Hospital, 1991. 
OSCARSON, D. W.; HUANG, P. M.; HAMMER, U. T.; LIAW, W. K. Oxidation and Sorption of Arsenite By Manganese-Dioxide As Influenced By Surface-Coatings of Iron and Aluminum-Oxides and Calcium-Carbonate. Water Air And Soil Pollution, v. 20, n. 2, p. 233-244, 1983. https://doi.org/10.1007/BF00279633

R DEVELOPMENT CORE TEAM. R-plus® 3.4.2. Software. Zurich, 2017

REDMAN, A. D.; MACALADY, D. L.; AHMANN, D. Natural organic matter affects Arsenic speciation and sorption onto hematite. Environmental Science and Technology, v. 36, n. 13, p. 2889-2896, 2002. https://doi.org/10.1021/es0112801

SINGH, A.; SHARMA, R. K.; AGRAWAL, M.; MARSHALL, F. M. Health risk assessment of heavy metals via dietary intake of foodstuffs from the wastewater irrigated site of a dry tropical area of India. Food and Chemical Toxicology, v. 48, n. 2, p. 611-619, 2010. https://doi.org/10.1016/j.fct.2009.11.041

TAYLOR, S.; MCLENNAN, S. The geochemical evolution of the continental crust. Reviews of Geophysics, v. 33, n. 2, p. 241-265, 1995. https://doi.org/10.1029/95RG00262

THUONG, N. T.; YONEDA, M.; IKEGAMI, M.; TAKAKURA, M. Source discrimination of heavy metals in sediment and water of to Lich River in Hanoi City using multivariate statistical approaches. Environmental Monitoring and Assessment, v. 185, n. 10, p. 8065-8075, 2013. https://doi.org/10.1007/s10661-013-3155-x

TUREKIAN, K. K.; WEDEPOHL, K. H. Distribution of the Elements in Some Major Units of the Earth's Crust. Geological Society of America Bulletin, v. 72, n. 2, p. 175-192, 1961. https://doi.org/10.1130/0016-7606(1961)72[175:DOTEIS]2.0.CO;2

USEPA. Method 3051a - Microwave assisted acid digestion of sediments, sludges, soils, and oils. Washington: USEPA, 1998.

USEPA. Guidelines for Water Reuse. Washington: USEPA, 2012.

VAROL, M. Assessment of heavy metal contamination in sediments of the Tigris River (Turkey) using pollution indices and multivariate statistical techniques. Journal of Hazardous Materials, v. 195, p. 2011. https://doi.org/10.1016/j.jhazmat.2011.08.051

WANG, M.; LIU, R.; LU, X.; ZHU, Z.; WANG, H.; JIANG, L.; LIU, J.; WU, Z. Heavy Metal Contamination and Ecological Risk Assessment of Swine Manure Irrigated Vegetable Soils in Jiangxi Province, China. Bulletin of Environmental Contamination and Toxicology, v. 100, n. 5, p. 634-640, 2018. https://doi.org/10.1007/s00128-018-2315-7

WHO. WHO guidelines for the safe use of wastewater, excreta and greywater: volume II. Geneva: World Health Organization, 2006.

XIE, Z. M.; HUANG, C. Y. Control of arsenic toxicity in rice plants grown on an arsenicpolluted paddy soil. Communications in Soil Science and Plant Analysis, v. 29, n. 1516, p. 2471-2477, 1998. https://doi.org/10.1080/00103629809370125 